\title{
Gene flow among habitat patches on a fragmented landscape in the spider Argiope trifasciata (Araneae: Araneidae)
}

\author{
MARTIN G. RAMIREZ* $\dagger \&$ KIRSTEN E. HAAKONSEN $\dagger$ \\ $\dagger$ Department of Biology, Loyola Marymount University, Los Angeles, CA 90045, U.S.A. \\ and $\ddagger$ New Canaan Country School, New Canaan, CT 06840, U.S.A.
}

\begin{abstract}
The banded garden spider (Argiope trifasciata) is a common orb weaver of old field habitats in the United States. In this study, we determined levels of genetic variability and gene flow among seven populations in central Pennsylvania, based on variation at eight allozyme loci. Mean heterozygosity (observed) per population was $7.5 \%$ and mean polymorphism was $39.3 \%$, consistent with levels of variability in other arthropods. Values of $G_{\mathrm{ST}}$ for the four polymorphic loci (mean $G_{\mathrm{ST}}=0.011$ ) suggest that gene flow prevents the genetic differentiation of these populations. The average number of migrants per generation $(\mathrm{Nm})$ among these populations is estimated to be 31.3. The lack of significant interpopulation genetic differentiation among these disjunct populations may result from spiderling aerial dispersal (ballooning), a more continuous distribution of suitable habitat in the past, and perhaps the use of roadside vegetation as gene flow corridors. On the other hand, the study populations did not exhibit isolation-by-distance, suggesting that suitable habitat in our study area is experienced as less than continuous by $A$. trifasciata. Thus, although $A$. trifasciata is an excellent ballooner, ballooning does not confer unlimited access among all populations, which suggests that ballooning may be a far less effective means of long-distance dispersal than previously thought.
\end{abstract}

Keywords: allozymes, Argiope trifasciata, gene flow, habitat fragmentation, population genetics, spider.

\section{Introduction}

Worldwide, rapidly expanding human development is encroaching upon and subdividing natural areas (Murphy, 1988). Fragmentation of the landscape produces a series of remnant vegetation patches surrounded by a matrix of different vegetation and/or land use. The ability of an organism to move among such remnants depends on the distance of individual remnants from other areas of native vegetation and the dispersal mode of the species. Aerially dispersed organisms are most likely to have the physical ability to traverse the sometimes long distances which can separate remnants, but they may lack the behavioural repertoire to cross the surrounding matrix. The matrix may be a particularly significant barrier for small-sized animals; for example, $100 \mathrm{~m}$ of agricultural fields has been shown to be a complete barrier to dispersal for some species of beetles and spiders (Mader, 1984). Determining levels of gene flow among biota occupying fragmented areas is be-

*Correspondence. E-mail: mramirez@1mumail.lmu.edu coming increasingly common and can significantly affect management recommendations (e.g. Dole \& Sun, 1992).

The banded garden spider, Argiope trifasciata, is abundant in the United States and their large orb webs are common in the vegetation of old field habitats (Horton \& Wise, 1983). Argiope trifasciata has an annual life-cycle; spiderlings emerge from over-wintering eggsacs in spring and adults may be collected from summer to early fall (McReynolds \& Polis, 1987). Tolbert (1977) found that the vast majority $(92 \%)$ of A. trifasciata spiderlings disperse via ballooning (aerial transport on wind-blown silk threads) and may reballoon if necessary to search for suitable web sites; once chosen, web site fidelity is quite high $(90 \%)$ (Enders, 1975). Thus, ballooning would seem to make A. trifasciata supremely adapted for the colonization of newly opened, ephemeral sites, as well as for the maintenance of significant genetic exchange among existing populations. However, levels of interpopulation gene flow have not been determined for any Argiope species and have been estimated for only a single araneid (Ramirez \& Fandino, 1996). 
In many parts of the eastern United States, the landscape is dominated by forest and agricultural land. This is especially true of Pennsylvania, where the land area is largely forest $(65 \%)$ and agricultural areas (30\%) (League of Women Voters of Pennsylvania, 1989). The Ridge and Valley Province of central Pennsylvania has a long history of domination by oaks (Quercus spp.), with mainly white, red, black and chestnut oaks $(Q$. alba, $Q$. rubra, $Q$. velutina and $Q$. montana) on mountain slopes and white oak on valley floors (Hawkes \& Abrahamson, 1994). Agriculture takes place in the valleys, primarily dairy and grain farming (Somerset Publishers, 1983). Thus, fragments of old field habitat in this region often resemble islands in a sea of forest and agriculture, as they can have discrete boundaries and are separated by habitat types that can serve as potential barriers to interpatch movement. On the other hand, for old field spiders such as Argiope spp. that can also reside in gardens, around houses and along roadsides (Enders, 1973; Gertsch, 1979), the central Pennsylvania landscape may be experienced as far more continuous, allowing genes to 'diffuse' via intermediate populations, leading to a pattern of isolation-by-distance (Wright, 1943). In this study, we present the results of an analysis of the amount and distribution of genetic variation within and among $A$. trifasciata populations occupying the fragmented landscape of central Pennsylvania, as well as estimate levels of interpopulation gene flow.

\section{Materials and methods}

\section{Collections}

During September and October 1995, we collected A. trifasciata from seven sites in Northumberland and Union Counties, Pennsylvania, on both sides of the west branch of the Susquehanna River (hereinafter referred to as the Susquehanna River) (Fig. 1). All sites were weedy patches or fields situated along roads in a matrix of farmland, forest and/or urban land. Spiders were collected from tall grass and herbaceous vegetation at all sites. Sample sizes ranged from 17 to 24 for a total of 145 spiders. In the laboratory, specimens were kept frozen at $-85^{\circ} \mathrm{C}$ until they were prepared for electrophoresis.

\section{Electrophoresis}

Enzyme electrophoresis generally followed Ramirez (1990). Gels were $12.5 \%$ starch (Sigma). Eight enzymes encoded by eight genetic loci were analysed: arginine phosphokinase $(A P K)$, aspartate aminotransferase $(A A T)$, glucosephosphate isomerase $(G P I)$, glyceraldehyde-3-phosphate dehydrogenase $(G-3-P D H)$, hexokinase

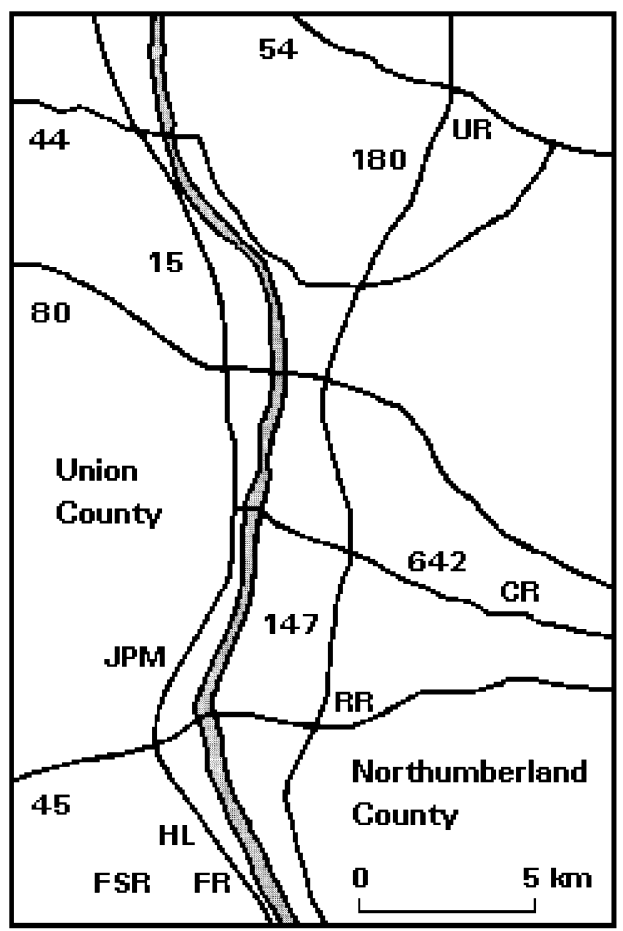

Fig. 1 Location of seven sites in Northumberland and Union Counties, Pennsylvania, sampled for Argiope trifasciata. Numbers indicate interstate highways $(80,180)$ and primary federal/state routes $(15,44,45,54,147,642)$; shading indicates the west branch of the Susquehanna River. Population abbreviations are as follows: Northumberland County: Creek Road (CR), US 180/Route 54 intersection (UR), Route 147/ Route 45 intersection (RR); Union County: J. P. M. Road (JPM), Hardscrabble Lane (HL), Furnace Road (FR), Furnace Road/Stein Road intersection (FSR).

$(H K)$, lactate dehydrogenase $(L D H)$, phosphoglucomutase $(P G M)$ and superoxide dismutase $(S O D)$. These enzymes were resolved using two buffer systems: Discontinuous Tris-Citrate I (Poulik, 1957) $[A P K, G P I$, $H K, L D H, P G M, S O D]$ and Continuous Tris-Citrate I (Selander et al., 1971) [AAT, G-3-PDH].

\section{Data analysis}

We used the BIOSYs-1 (Swofford \& Selander, 1981), DIST (Slatkin, 1993) and GENEPOP (Raymond \& Rousset, 1995) computer packages to analyse the electrophoretic data. Agreement between population genotypic proportions and Hardy-Weinberg expectations was evaluated by calculation of exact significance probabilities (Haldane, 1954), as well as via a global test across loci (Raymond \& Rousset, 1995). The degree of population differentiation was analysed by calculation of Nei's (1973) $G_{\mathrm{ST}}$ between population pairs based on the allele frequencies at each locus. Slatkin \& Barton (1989) have 
Table 1 Allele frequencies for polymorphic loci in seven populations of Argiope trifasciata. Population abbreviations follow Fig. 1; locus abbreviations are given in the text; sample sizes are given in parentheses

\begin{tabular}{cccccccc}
\hline & \multicolumn{3}{c}{ Population } & & & \\
\cline { 2 - 8 } Locus/allele & CR & UR & RR & JPM & HL & FR & FSR \\
\hline$A A T$ & $(20)$ & $(20)$ & $(20)$ & $(23)$ & $(24)$ & $(17)$ & $(21)$ \\
$A$ & 0.000 & 0.025 & 0.025 & 0.022 & 0.021 & 0.029 & 0.071 \\
$B$ & 0.925 & 0.975 & 0.975 & 0.978 & 0.979 & 0.971 & 0.929 \\
$C$ & 0.075 & 0.000 & 0.000 & 0.000 & 0.000 & 0.000 & 0.000 \\
$G P I$ & $(20)$ & $(20)$ & $(20)$ & $(23)$ & $(24)$ & $(17)$ & $(21)$ \\
$A$ & 0.175 & 0.050 & 0.000 & 0.043 & 0.104 & 0.147 & 0.095 \\
$B$ & 0.725 & 0.725 & 0.800 & 0.717 & 0.708 & 0.647 & 0.786 \\
$C$ & 0.100 & 0.225 & 0.200 & 0.239 & 0.188 & 0.206 & 0.119 \\
$H K$ & $(20)$ & $(20)$ & $(20)$ & $(23)$ & $(24)$ & $(17)$ & $(21)$ \\
$A$ & 1.000 & 0.975 & 1.000 & 0.978 & 0.979 & 1.000 & 1.000 \\
$B$ & 0.000 & 0.000 & 0.000 & 0.000 & 0.021 & 0.000 & 0.000 \\
$C$ & 0.000 & 0.025 & 0.000 & 0.000 & 0.000 & 0.000 & 0.000 \\
$D$ & 0.000 & 0.000 & 0.000 & 0.022 & 0.000 & 0.000 & 0.000 \\
$P G M$ & $(20)$ & $(20)$ & $(20)$ & $(23)$ & $(24)$ & $(17)$ & $(21)$ \\
$A$ & 0.000 & 0.000 & 0.000 & 0.000 & 0.000 & 0.029 & 0.000 \\
$B$ & 0.000 & 0.025 & 0.050 & 0.043 & 0.000 & 0.000 & 0.000 \\
$C$ & 0.975 & 0.925 & 0.925 & 0.957 & 1.000 & 0.971 & 1.000 \\
$D$ & 0.000 & 0.000 & 0.025 & 0.000 & 0.000 & 0.000 & 0.000 \\
$E$ & 0.000 & 0.050 & 0.000 & 0.000 & 0.000 & 0.000 & 0.000 \\
$F$ & 0.025 & 0.000 & 0.000 & 0.000 & 0.000 & 0.000 & 0.000 \\
\hline
\end{tabular}

shown that $G_{\mathrm{ST}}$ serves as a good estimator of Wright's (1931) $F_{\mathrm{ST}}$, which is mathematically related to gene flow $(N m)$ by the equation: $N m=\left(1-F_{\mathrm{ST}}\right) / 4 F_{\mathrm{ST}}$ (Wright, 1931). We also determined values of Weir \& Cockerham's (1984) $\Theta$, another estimator of $F_{\mathrm{ST}}$, for population pairs. However, because some values of $\Theta$ were negative for some comparisons, we were able to estimate gene flow among all pairs of populations using only the $G_{\mathrm{ST}}$-based estimates of $\mathrm{Nm}$.

Finally, we examined the data for evidence of isolation-by-distance in our study area. To do this, we performed linear regression of estimates of $F_{\mathrm{ST}} /$ $\left(1-F_{\mathrm{ST}}\right)$ between all pairs of populations against the logarithms of interpopulation map distances (in $\mathrm{km}$ ), following Rousset (1997). Weir \& Cockerham's (1984) $\Theta$ was used as the estimator of $F_{\mathrm{ST}}$. To estimate the significance of this regression relationship, we conducted a Mantel (1967) test, performing 5000 randomizations for the analysis (Raymond \& Rousset, 1995).

\section{Results}

Four loci ( $A P K, G-3-P D H, L D H, S O D)$ were monomorphic across all seven populations. The four other loci ( $A A T, H K, G P I, P G M$ ) were polymorphic for two or more alleles in at least three sites (Table 1).

\section{Population variability}

In general, A. trifasciata populations show moderate levels of genetic variability (Table 2). The mean number of alleles per locus was 1.5 (range 1.4-1.8), mean heterozygosity (observed) was 0.075 (range 0.060 0.096 ), and mean polymorphism was $39.3 \%$ (range 25.0-50.0\%). Of the 22 tests against Hardy-Weinberg

Table 2 Genetic variability measures for the seven study populations of Argiope trifasciata

\begin{tabular}{lccccc}
\hline Population & $N$ & $A$ & $P$ & $H_{\mathrm{o}}$ & $H_{\mathrm{e}}$ \\
\hline CR & 20.0 & 1.5 & 37.5 & 0.081 & 0.080 \\
UR & 20.0 & 1.8 & 50.0 & 0.069 & 0.085 \\
RR & 19.9 & 1.5 & 37.5 & 0.063 & 0.065 \\
JPM & 23.0 & 1.6 & 50.0 & 0.076 & 0.076 \\
HL & 24.0 & 1.5 & 37.5 & 0.078 & 0.068 \\
FR & 17.0 & 1.5 & 37.5 & 0.096 & 0.081 \\
FSR & 21.0 & 1.4 & 25.0 & 0.060 & 0.063 \\
\hline
\end{tabular}

$N$, mean sample size per locus; $A$, mean number of alleles per locus; $P$, percentage of loci polymorphic (a locus is considered polymorphic if the frequency of the most common allele does not exceed 0.99$) ; H_{\mathrm{o}}$, observed heterozygosity; $H_{\mathrm{e}}$, expected mean heterozygosity calculated using the unbiased estimate of Nei (1978). Population abbreviations and order follow Fig. 1. 


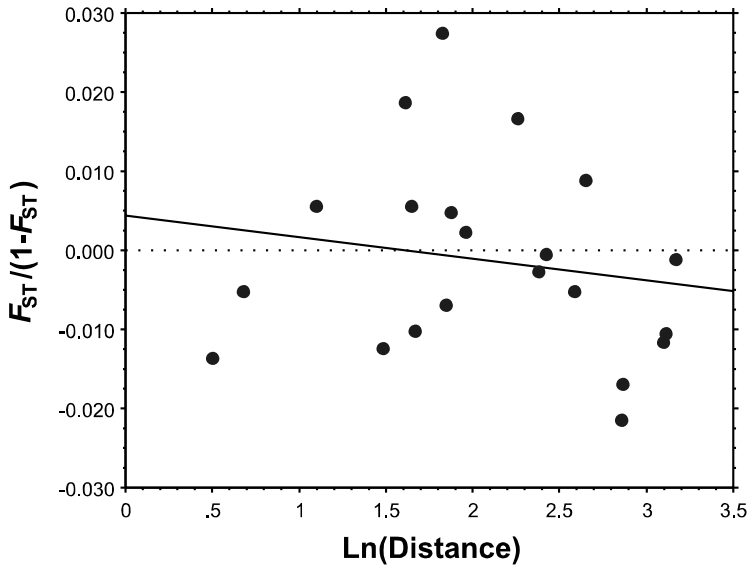

Fig. 2 Differentiation among Argiope trifasciata populations in central Pennsylvania. Multilocus estimates of pairwise differentiation are plotted against logarithm of map distances (in $\mathrm{km})$. The regression is $y=0.004-0.003 x(P=0.772)$ and the maximum distance between two populations is $23.6 \mathrm{~km}$. $F_{\mathrm{ST}}$ was estimated according to Weir \& Cockerham (1984).

predictions for polymorphic loci, no cases were found to violate predictions, and a global test across loci also indicated conformance to Hardy-Weinberg expectations. Thus, individual populations were genetically variable and in conformance with Hardy-Weinberg equilibrium.

\section{Interpopulation differentiation and gene flow}

These populations are minimally structured as indicated by values of $G_{\mathrm{ST}}$ and $\mathrm{Nm}$ for population pairs. On average, $\approx 1.1 \%$ of the total variance in allele frequencies in A. trifasciata was attributable to differences among populations (mean $G_{\mathrm{ST}}=0.011$ ). Using the $G_{\mathrm{ST}}$ values to estimate gene flow, the mean number of migrants per generation $(\mathrm{Nm})$ among these populations was 31.3. Wright (1931) determined that $\mathrm{Nm}>1$ is sufficient to overcome the effects of genetic drift and that $\mathrm{Nm}>4$ indicates that there has been general mixing of the populations. Hence, because the mean $\mathrm{Nm}$ value (31.3), as well as all the original pairwise values (range 9.2-118.6), are well above both 1 and 4 , these spatially separate A. trifasciata populations arrayed on opposite sides of the Susquehanna River form a single panmictic population.

\section{Isolation-by-distance}

Isolation-by-distance will generate a positive correlation between geographical distance (or its natural logarithm) and multilocus estimates of pairwise differentiation $\left[F_{\mathrm{ST}} /\right.$ $\left(1-F_{\mathrm{ST}}\right)$ (Raymond \& Rousset, 1995; Rousset, 1997). For $A$. trifasciata, analysis of $F_{\mathrm{ST}} /\left(1-F_{\mathrm{ST}}\right)$ plotted against the logarithm of map distance (in km) (Fig. 2) yields a slightly negative slope $(-0.003)$ and Mantel analysis indicates that this relationship is nonsignificant $(P=0.772)$. These results indicate that genetic differentiation in A. trifasciata in central Pennsylvania is not directly related to physical distance, as might be expected if these populations function genetically as an isolation-by-distance unit.

\section{Discussion}

\section{Population variability}

Argiope trifasciata populations are moderately variable and in Hardy-Weinberg equilibrium. The heterozygosity and polymorphism levels in individual populations are well within the range observed for spiders (including other araneids) and invertebrates in general (Ramirez \& Saunders, 1999).

\section{Gene flow}

Founder events, bottlenecks and random drift might well lead to considerable genic heterogeneity among spider populations occupying the isolated fields and weedy patches sampled in this study. However, the low values of $G_{\mathrm{ST}}$ and large values of $\mathrm{Nm}$ for $A$. trifasciata indicate that gene flow is sufficiently strong that it prevents these forces from causing significant genetic differentiation. Certainly, these results are likely to result largely from the ability of $A$. trifasciata spiderlings to disperse aerially via ballooning (Tolbert, 1977). On the other hand, the lack of an isolation-by-distance relationship among these populations suggests that suitable habitat in our study area is experienced as less than continuous by $A$. trifasciata. Thus, ballooning does not confer unlimited access among all populations, which is consistent with recent studies which suggest that ballooning may be far less of a long-range means of transport than was previously thought (Foelix, 1996). Nonetheless, A. trifasciata's dispersal abilities have clearly been sufficient to maintain significant genetic cohesion among isolated populations spanning a $24-\mathrm{km}$ north-east-south-west range (Fig. 1).

Historically, the central Pennsylvania landscape in our study area may have provided more suitable habitat for A. trifasciata prior to human-caused alterations, which would have facilitated historic opportunities for gene flow (e.g. Ramirez \& Fandino, 1996). Interestingly, as was mentioned earlier, gene flow in our study area may actually be enhanced by the presence of roads and highways in contemporary central Pennsylvania. Specifically, in a study of habitat selection by Argiope aurantia, Enders (1973) found that the highest population densities were in 'edge' habitats, as in the vegetation along highways and road cuts, and implied that the 
man-made ecotone along today's road systems might provide excellent dispersal routes. The role of roadsides as potential linear movement corridors for biota is now widely appreciated and there are numerous examples (Forman, 1995). Although ecological data to assess A. trifasciata's success in the roadside habitat do not exist, some of our sites (e.g. UR, RR) are comparable to the road/highway sites studied by Enders (1973) and A. trifasciata were abundant. Clearly, a more detailed study involving both direct (marking) and indirect (genetic) means to determine movement among habitat patches along roadways will be needed to assess their potential gene flow significance for A. trifasciata.

\section{Conservation implications}

Considerable genetic exchange among orb weaver populations in fragmented landscapes has now been documented for two araneids: Metepeira ventura occupying disjunct clumps of Opuntia cacti on Santa Catalina Island, California $(\mathrm{Nm}=28.6)$ (Ramirez \& Fandino, 1996); and A. trifasciata $(\mathrm{Nm}=31.3)$ (present study). These results suggest that araneids may have minimal difficulty maintaining genetic connectedness among populations situated in a matrix of largely unfavourable habitat. Although it is not known if $M$. ventura spiderlings balloon (Ramirez \& Fandino, 1996), spiderlings of most modern spiders (including araneids) commonly balloon (Dean \& Sterling, 1985) and in light of the present results with A. trifasciata (a ballooner), we suspect that a number of those which do may also be able to maintain genetic cohesion among populations in the face of habitat fragmentation, at least to some degree. We are presently conducting similar studies of both araneids and nonaraneids in fragmented landscapes to understand better the relationship between the landscape matrix and gene flow for spiders.

\section{Acknowledgements}

We thank C. P. Blair for laboratory assistance. Financial support was provided by a Bucknell University scholarly development grant to M.G.R.

\section{References}

DEAN, D. A. AND STERLING, w. L. 1985. Size and phenology of ballooning spiders at two locations in eastern Texas. J. Arachnol., 13, 111-120.

DOLE, J. A. AND SUN, M. 1992. Field and genetic survey of the endangered Butte County meadowfoam - Limnanthes floccosa subsp. californica (Limnanthaceae). Conserv. Biol., 6, 549-558.
ENDERS, F. 1973. Selection of habitat by the spider Argiope aurantia Lucas (Araneidae). Am. Midl. Nat., 90, 47-55.

ENDERS, F. 1975. Change of web site in Argiope spiders (Araneidae). Am. Midl. Nat., 94, 484-490.

FOEliX, R. F. 1996. Biology of Spiders, 2nd edn. Oxford University Press, Oxford.

FORMAN, R. T. T. 1995. Land Mosaics: The Ecology of Landscapes and Regions. Cambridge University Press, Cambridge.

GERTSCH, w. J. 1979. American Spiders, 2nd edn. Van Nostrand Reinhold, New York.

HALDANE, J. B. S. 1954. Heterozygote frequencies in small populations. Theor. Pop. Biol., 8, 31-48.

HAWKeS, C. V. AND ABRAHAMSON, W. G. 1994. Vegetation and succession on a central Pennsylvania limestone synclinal ridge. J. Pennsylvania Acad. Sci., 68, 99-106.

HORTON, C. C. AND WISE, D. H. 1983. The experimental analysis of competition between two syntopic species of orb-web spiders (Araneae: Araneidae). Ecology, 64, 929-944.

LEAGUE OF WOMEN VOTERS OF PENNSYLVANIA. 1989. Key to the Keystone State: Pennsylvania, 4th edn. Pennsylvania State University Press, University Park, PA.

MADER, H.-J. 1984. Animal habitat isolation by roads and agricultural fields. Biol. Conserv., 29, 81-96.

MANTEL, N. 1967. The detection of disease clustering and a generalized regression approach. Cancer Res., 27, 209220.

McREYNOLDS, C. N. AND POLIS, G. A. 1987. Ecomorphological factors influencing prey use by two sympatric species of orb web spiders, Argiope aurantia and Argiope trifasciata (Araneidae). J. Arachnol., 15, 371-383.

MURPHY, D. D. 1988. Challenges to biological diversity in urban areas. In: Wilson, E. O. (ed.) Biodiversity, pp. 71-76. National Academy Press, Washington, DC.

NEI, M. 1973. Analysis of gene diversity in subdivided populations. Proc. Natl. Acad. Sci. U.S.A., 70, 3321-3323.

NEI, M. 1978. Estimation of average heterozygosity and genetic distance from a small number of individuals. Genetics, 89, 583-590.

POULIK, M. D. 1957. Starch gel electrophoresis in a discontinuous system of buffers. Nature, 180, 1477-1479.

Ramirez, M. G. 1990. Natural History, Population Genetics, Systematics and Biogeography of the Spider Genus Lutica (Araneae: Zodariidae). Ph.D. Thesis, University of California, Santa Cruz.

RAMIREZ, M. G. AND FANDINO, L. B. 1996. Genetic variability and gene flow in Metepeira ventura (Araneae, Araneidae). J. Arachnol., 24, 1-8.

RAMIREZ, M. G. AND SAUNDERS, T. A. 1999. Allozyme diversity in non-social spiders: Pattern, process and conservation implications. J. Insect Conserv., 3, in press.

RAYMOND, M. AND ROUSSET, F. 1995. GENEPOP (version 1.2): Population genetics software for exact tests and ecumenicism. J. Hered., 86, 248-249.

ROUSSET, F. 1997. Genetic differentiation and estimation of gene flow from $F$-statistics under isolation by distance. Genetics, 145, 1219-1228. 
SELANDER, R. K., SMITH, M. H., YANG, S. Y., JOHNSON, W. E. AND GENTRY, J. B. 1971. Biochemical polymorphism and systematics in the genus Peromyscus. I. Variation in the old-field mouse (Peromyscus polionotus). Stud. Genet., 6, 49-90.

SLATKIN, M. 1993. Isolation by distance in equilibrium and non-equilibrium populations. Evolution, 47, 264-279.

SLATKIN, M. AND BARTON, N. H. 1989. A comparison of three indirect methods for estimating average levels of gene flow. Evolution, 43, 1349-1368.

SOMERSET PUBLISHERS. 1983. Encyclopedia of Pennsylvania. Somerset Publishers, St. Clair Shores, MI.
SWOFFORD, D. L. AND SELANDER, R. B. 1981. BIOSYS-1: a FORTRAN program for the comprehensive analysis of electrophoretic data in population genetics and systematics. J. Hered., 72, 281-283.

TOLBERT, w. w. 1977. Aerial dispersal behavior of two orb weaving spiders. Psyche, 84, 13-27.

WEIR, B. S. AND COCKERHAM, C. C. 1984. Estimating $F$-statistics for the analysis of population structure. Evolution, 38, 1358-1370.

WRIGHT, s. 1931. Evolution in Mendelian populations. Genetics, 16, 97-159.

WRIGHT, s. 1943. Isolation by distance. Genetics, 28, 139-156. 